\title{
Anomalous origin of the coronary artery from the pulmonary artery in a 33-year-old man
}

\author{
Dominika M Zoltowska, ${ }^{1}$ Yashwant Agrawal, ${ }^{2}$ Guramrinder Singh Thind, ${ }^{1}$ \\ Jagadeesh K Kalavakunta ${ }^{3}$
}

'Department of Internal Medicine, Western Michigan University School of Medicine, Kalamazoo, Michigan, USA ${ }^{2}$ Western Michigan University Homer Stryker School of Medicine, Kalamazoo, Michigan, USA

${ }^{3}$ Cardiology, Borgess Medical Center, Kalamazoo, Michigan, USA

\section{Correspondence to}

Dr Dominika M Zoltowska dominika.zoltowska@med. wmich.edu

Accepted 27 April 2018
Check for updates

To cite: Zoltowska DM, Agrawal Y, Thind GS, et al. BMJ Case Rep Published Online First: [please include Day Month Year]. doi:10.1136/bcr-2018225310

\section{DESCRIPTION}

A 33-year-old man, without prior history of coronary artery disease, was referred to a catheterisation laboratory with a diagnosis of non-ST elevation myocardial infarction. Coronary angiogram showed a dilated, dominant right coronary artery of normal origin with multiple collaterals draining to the left coronary system (figure $1 \mathrm{~A}, \mathrm{~B}$ ) and a coronary 'steal' phenomenon into the pulmonary artery (PA). Left main coronary artery (LMA) was not visualised on contrast injection into the aortic root (figure 1B). Ventriculogram showed ejection fraction of $40 \%-45 \%$ and anterior wall hypokinesis. Subsequent three-dimensional heart computer tomogram revealed anomalous origin of the LMA from PA, (figure 1C), confirming the diagnosis of anomalous origin of the coronary artery from the pulmonary artery (ALCAPA).

ALCAPA, also known as Bland-White-Garland syndrome, is a rare anomaly with estimated prevalence of 1:300000 and high mortality rate in early childhood if left untreated. Very rarely it can be associated with other cardiac anomalies such as septal defects, coarctation of aorta, patent ductus arteriosus and tetralogy of Fallot. ${ }^{1}$ In our case, we did not see any other cardiac anomalies except redundant mitral leaflets with minimal prolapse (video 1 ). There are only a few survivors diagnosed in adulthood, presenting with various clinical symptoms, most commonly dyspnoea and angina. ${ }^{2}$ Surgery is the mainstream therapy. Our patient underwent left coronary artery (LCA) reimplantation to the aorta without complications. Successful treatment with coronary artery
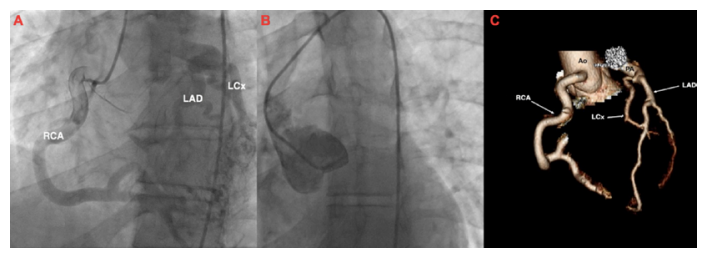

Figure 1 (A) Left anterior oblique (LAO) view. Large dominating RCA with extensive collaterals to the left coronary system. (B) Failure to visualise left coronary artery on contrast injection to the left coronary cusp. (C) Three-dimensional computer reconstruction of coronary arteries showing anomalous origin of the left coronary artery system from the PA. Ao, aorta; $L A D$, left anterior descending artery; $L C x$, left circumflex artery; PA, pulmonary artery; RCA, right coronary artery.

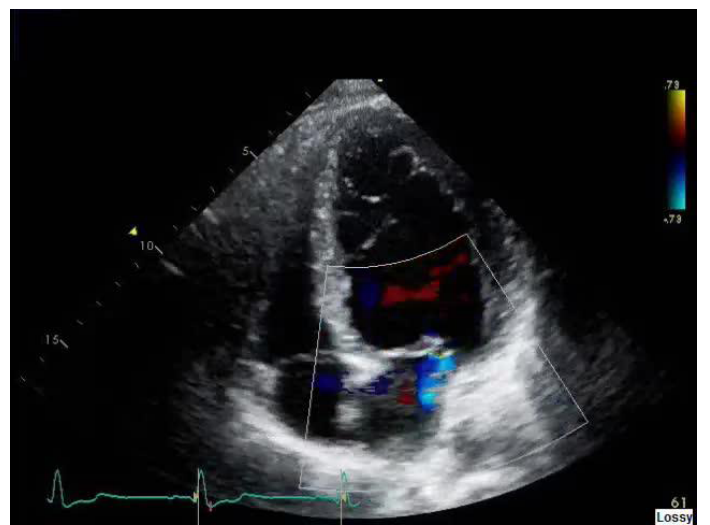

Video 1 Transthoracic echocardiogram with Doppler studies revealing trace mitral prolapse.

\section{Learning points}

- Anomalous coronary arteries as important differential diagnosis of chest pain in young population.

- The importance of diagnosis and treatment of anomalous origin of the coronary artery from the pulmonary artery to prevent mortality and mortality.

- The utilisation of three-dimensional heart computer tomography to establish the anatomy of anomalous coronary arteries.

bypass grafting combined with LCA ligation from the PA was also reported.

Contributors All authors were the physicians in charge of the patient throughout hospitalisation and follow-up. DMZ and JK were responsible for performing, diagnosing and discussing the imaging studies of the patient. DMZ prepared the manuscript draft, which was critically revised by YA, GST and JK, and approved by all authors.

Funding This research received no specific grant from any funding agency in the public, commercial or not-for-profit sectors.

Competing interests None declared.

Patient consent Obtained.

Provenance and peer review Not commissioned; externally peer reviewed.

(C) BMJ Publishing Group Ltd (unless otherwise stated in the text of the article) 2018. All rights reserved. No commercial use is permitted unless otherwise expressly granted.

\section{REFERENCES}

1 Khanna A, Torigian DA, Ferrari VA, et al. Anomalous origin of the left coronary artery from the pulmonary artery in adulthood on CT and MRI. AJR Am J Roentgenol 2005;185:326-9. 


\section{Images in...}

2 Boutsikou M, Shore D, Li W, et al. Anomalous left coronary artery from the pulmonary artery (ALCAPA) diagnosed in adulthood: Varied clinical presentation, therapeutic approach and outcome. Int J Cardio/ 2018;261:49-53.
3 Alsara 0, Kalavakunta JK, Hajjar V, et al. Surviving sudden cardiac death secondary to anomalous left coronary artery from the pulmonary artery: a case report and literature review. Heart Lung 2014;43:476-80.

Copyright 2018 BMJ Publishing Group. All rights reserved. For permission to reuse any of this content visit http://group.bmj.com/group/rights-licensing/permissions.

BMJ Case Report Fellows may re-use this article for personal use and teaching without any further permission.

Become a Fellow of BMJ Case Reports today and you can:

- Submit as many cases as you like

- Enjoy fast sympathetic peer review and rapid publication of accepted articles

- Access all the published articles

- Re-use any of the published material for personal use and teaching without further permission

For information on Institutional Fellowships contact consortiasales@bmjgroup.com

Visit casereports.bmj.com for more articles like this and to become a Fellow 